\title{
An Analysis of the Enlightenment of Greek and Roman Mythology to English Language and Literature
}

\author{
Hong Liu \\ Foreign Languages School, Yunnan Agricultural University, Kunming Yunnan, 650201,China
}

Keywords: Greek and Roman mythology, English, language and literature, Enlightenment.

\begin{abstract}
In the long course of history, Greek and Roman mythology has gradually formed specific cultural connotations after inheritance and development for thousands of years, exerting an extensive and far-reaching influence on the language and culture in the western society, and even penetrating into English language and literature in every regard. This paper analyzed the origin of Greek and Roman mythology, and based on an exploration of the relationship between Greek and Roman mythology and English language and literature, made a proper analysis of the enlightenment of Greek and Roman mythology to English language and literature, hoping to provide some support for the further development of English language and literature.
\end{abstract}

\section{Introduction}

In ancient Greece, the social economy was relatively developed, which promoted that the ancient Greek and Roman cultures began to show an obvious tendency of prosperous development to a certain extent, thus laying a solid foundation for the formation of the ancient Greek and Roman culture system, and prompting the ancient Greek and Roman cultures to render a scene of prosperous development in the history, while exerting an especially significant influence on the formation and further evolution of the overall European culture system. The English language was also formed under the common action of the ancient Greek culture and Latin, and its own development will be inevitably influenced by the transmission of the ancient Greek and Roman cultures. Therefore, the research on English language and literature should also pay proper attention to the topic of Greek and Roman mythology. Researches have shown that an in-depth exploration of English language and literature from the perspective of Greek and Roman mythology can promote the research on English language and literature to get better development.

\section{Origin of Greek and Roman Mythology}

Greece and Rome were important cradles of western culture. Western culture was constantly transmitted and diffused in the two regions in the form of oral literature at the beginning of its formation, Later, the literary form of western culture was standardized to some extent after the culture was organized by people including Home. Western culture was divided into two important parts, namely, fairy tales and legendary heroes, and then was gradually widely spread in Europe, thus having a specific impact on the development of European language and literature. In the Greek and Roman mythology system, the story of god mainly includes contents such as the development of the heaven and the earth, and daily production life of gods, which reflects the origin of human beings to a certain degree. However, it should be noted in the research that the ancient mythological literature generally has strong fictionality, and thus in the process of literary researches, we should also attach importance to the fictionality of mythology and the authenticity of history simultaneously in order to ensure the comprehensiveness of researches. With the fight between heroes and dark forces and the 
fight against monsters as main contents, the transmission of stories about legendary heroes in Greek and Roman mythology generally tends to carry out the artistic creation of related heroic figures in the context of real stories, and then a combination of legendary heroes and fairy tales for the formation of Greek and Roman mythology with a unique charm, which not only achieves people's inheritance of the ancient Greek and Roman cultural heritage, but also reflects people's fantasy of world and life thousands of years ago and thus demonstrates their reflections of human beings on life and livelihood as well as their exploration of nature to some extent.

The ancient Greek and Roman cultures gradually formed a specific unity in the process of development, mainly because after the Greek culture was spread to the Rome area and had a specific impact on the spirit and thought of Romans, the Greek culture gradually attracted the attention of Roman leaders and grass-root people and thus was inherited and transmitted in Rome as an important cultural thought, thus prompting the ancient Greek and Roman cultures to get spread to a certain extent. It is not difficult to find that the Roman culture was originally produced in the primitive society, and then inherited in the form of oral literature. Until letters appeared, Greek and Roman mythology got a real record and then was inherited and transmitted for a long time. In 197 BC, Rome defeated Macedonia in the war, then Greece became a Roman territory, and the rich and splendid culture in Greece exerted a specific influence on the Roman society, and even promoted Roman people to accept the Gods worshiped in the Greek culture to a certain degree. Afterwards, after a long period of research and development, Greek and Roman mythology has gradually formed a unified whole, thus exerting a profound impact on the formation of the western culture system, and playing an important enlightening role in the research on English language and literature.

\section{Relationship between English Language and Literature and Greek and Roman Cultures}

From a comprehensive analysis of the basic development history of English language and literature, it can be found that the British Isles bore the important task of connecting the Mediterranean and waterways on the European continent in 40,000 or 5,000 BC, and invaders appeared continuously in the $7^{\text {th }}$ century BC and occupied most of the British territory, which deepened the close ties between Celtics and Gauls on the British Isles to a certain extent. Besides, Gauls provided some support for the war of Celtics, which directly resulted in that the army of Julius Caesar expanded the scope of conquest towards the surrounding islands after conquering the Gaul, and eventually, really occupied and conquered the British Isles in $43 \mathrm{BC}$ and then ruled it for more than 300 years. ${ }^{[1]}$ Thereafter until the late Middle Ages, all ethnic groups in Europe gradually completed the division and occupation of their respective national territories, the regional culture with European characteristics and a rich national culture gradually formed, and European language and literature was enriched to some extent. However, English language and literature is an extremely important component part in a variety of languages and literatures. Under the action of English language and literature, the British people have a relatively high national consciousness, and thus have created a large number of language and literature works with obvious ethnic cultural characteristics. From a comprehensive research and analysis of these language and literature works, it can be found that language and literature works created in this period are obviously influenced by the Creco-Roman culture. Visibly, the Creco-Roman culture has been fully inherited and transmitted in the English language and literature creation, and will have a certain positive impact on the future development of the Creco-Roman culture and the English language and literature.

\section{Influence and Enlightenment of Greek and Roman Mythology on English Language and Literature}

\section{Influence of Greek and Roman mythology on the English language and literature creation}

Greek and Roman mythology is one of the world's most important cultural heritages in Europe currently. By virtue of the Roman invasion and occupation of other countries, Greek and Roman 
mythology was spread gradually and relatively widely within Europe. In the Renaissance period, Greek and Roman mythology had a relatively significant impact on the development and inheritance of European literature and art. Not only Greek and Roman mythology provided a wealth of materials for literary and artistic creation, but also literature and art researchers again gave new vitality and life connotations to the ancient mythological figures in the process of their repeated researches on mythology and restoration of literature ${ }^{[2]}$. Thus it can be seen that English language and literature in the western society exactly formed and developed gradually in the process of mutual promotion between the Creco-Roman culture and the literature and art, so it will be inevitably influenced by Greek and Roman mythology.

Starting from the Renaissance, the Creco-Roman culture has been widely spread in the European society with the power of the Renaissance, prompting European people to develop an increasing strong interest in reading Greek and Roman mythology. Many outstanding works created by literary artists are closely related with Greek and Roman mythology. For example, Shakespeare's work Troilus And Cressida and Milton's representative work Comus both took Greek and Roman culture as an important theme for the English language and literature creation, and gave these works a unique cultural and artistic charm. Particularly, Milton's representative work Comus was particularly evident in the regard since Milton made a reasonable integration of more than 30 figures in Greek and Roman mythology in the creative process, and chose their stories as creation sources for the English language and literature creation, thus achieving a great success and exerting a corresponding influence on the development of English language and literature. Subsequently, the poets including Keats and Shelley also began to integrate mythical elements in the process of literary creation, which not only demonstrated the inheritance of fairy tales, but also expressed certain emotions and conveyed their own thoughts and feelings with Greek and Roman mythology as the carrier. In short, a strong fighting will and the power of superhuman exhibited by mythological figures and historical heroes in Greek and Roman mythology have played a certain incentive role in the thinking and imagination of literary creators. So to speak, the creators of literature and art make an integration of fairy tales and the English literature and art creation, while the works of literary creators include their new interpretation of mythological figures, which can be even said that creators give new vitality to Greek and Roman mythology. Therefore, Greek and Roman mythology has been influenced by the English language and literature creation to some extent. However, on the whole, to make English language and literature get better development, we should make a careful analysis of the influence of Greek and Roman mythology, and then make clear the development direction of the English language and literature creation in order to give right guidelines to the English language and literature creation.

\section{Enlightenment of Greek and Roman mythology to the English language}

The enlightenment of Greek and Roman mythology to the English language in the process of inheritance is mainly manifested in English words and daily oral English communication. Generally speaking, the English language after a long period of development has shown distinctive characteristics of abundance and flexibility, and in the process of practical application, often uses the techniques of metaphor and personification to present a more vivid image. In the development process of the English language, the myth language has become an important part of everyday English expressions to a certain extent due to the long-term influence of Greek and Roman mythology. For example, Europe (Europa) comes from the Phoenician Princess who is the wife of Zeus in Greek and Roman mythology, and Paris is the name of Polis, the Prince of Troy. Thus it can be seen that fairy tales have been relatively widely applied in the English language cultural system, and even have become an important habit of English language and literature expressions. Related researches have shown that as many as more than 1,000 words in the rich system of English words come from Greek and Roman mythology, and these words have formed new connotations in the evolution process of language, exerting a certain impact on the English language and literature creation $^{[3]}$. In general, the words derived from Greek and Roman mythology in the English language system can be divided into two main types, namely, common words and professional words. 
Common words are generally evolved from the titles of gods or related key things in fairy tales, while professional words (terminology) is generally formed in artistic production or specific industry sectors, and these words are mostly monosemic words.

\section{Enlightenment of Greek and Roman mythology to English Language and Literature}

After a detailed research and summary, the enlightenment of Greek and Roman mythology to English language and literature is basically manifested in the following two aspects:

Firstly, Greek and Roman mythology enriches the vocabulary in English language and literature. Researches have shown that not only Greek and Roman mythology has a wealth of literary creation materials and a large English language vocabulary, but also its specific cultural creative idea also plays a certain enlightening role in the development of English language and literature ${ }^{[4]}$. For example, in the field of English language and literature, the term of "Pandora's box" is derived from a fairy tale as follows: "Pandora" is a life entity created by the spirit of gods. She opened the box containing all pains such as evil and disaster at her wedding with Zeus, and misfortunes in the world were generated accordingly. This fairy tale applied to the process of the English language and literature creation is often used to describe the root causes of disasters, and such examples are too numerous to mention. Visibly, fairly tales give specific language connotations to literary creation while enriching the English language. Greek mythology has been spread to today's society after cultural evolution and integration for thousands of years, and many stories have widely penetrated into all English-speaking countries, which not only exerts a specific impact on the English language and literature creation, but also plays a certain enlightening role in the English language and literature creation.

Secondly, Greek and Roman mythology inspires the creation of the English language and literature creators. Greek and Roman mythology has the distinguishing characteristics of easy to understand and vivid image, which not only can be widely circulated in English-speaking countries, and also actively promotes the English language and literature creators to make a combination of fairy tales and creation in the process of literary creation practice in order to show different literary tendencies. For example, the related works of the romantic genre in English language and literature are the important representatives of literary creation with the help of ancient Greek fairy tales ${ }^{[5]}$. Visibly, Greek and Roman fairy tales can inspire the creation of creators, prompt English language and literature creators to achieve better integration with fairy tales, and provide the corresponding support for the development of language and literature as well as the inheritance of mythology. Meanwhile, with the progress of the times, the literary creation environment in the $21^{\text {st }}$ century has undergone constant changes accordingly, which opens up a new territory for the inheritance and development of culture to some extent. Therefore, in the process of the English language and literature creation, creators can make proper use of fairy tales to convey their own thoughts, their dissatisfaction with the real society, and their vision for the future, thus promoting their literary works to cause the resonance of readers, ensuring their literary works to get affirmed by readers on the basis of revealing social phenomena, and creating conditions for the further development of English language and literature in the new era.

\section{Conclusion}

In summary, the Creco-Roman culture has been well inherited in the long process of evolution, exerting a certain influence on the English language and literature creation and actively promoting the development of English language and literature in the process of culture transmission. Therefore, to make English language and literature creation obtain greater development results in the context of the current era, we should further strengthen the focus on the transmission of Greek and Roman mythology, gain a profound grasp of the enlightenment of Greek and Roman mythology to the English language and literature creation through an in-depth research and analysis of the influence of Greek and Roman mythology on the English language literature creation, and give right guidelines to the optimization and expansion of the English language and literature creation. 


\section{References}

[1] Han Dongxue. On the Influence of Greek and Roman Mythology on English Language and Literature, Science and Technology Innovation Herald, 2014 (18): 212-212.

[2] Ma Hongji. On the Enlightenment of Greek and Roman Mythology to English Language and Literature, Business Stories, 2015 (14): 68-69.

[3] Li Ziyao. An Exploration of the Enlightenment of Greek and Roman Mythology to English Language and Literature, Youth Literators, 2015 (12): 120-120.

[4] Xing Qiudi. On the Influence of Greek and Roman Mythology on English Language and Literature, Youth Literators, 2013 (18): 12-13.

[5] Ge Youjin. Students Majoring in English Language and Literature Should Strengthen the Study of Greek and Roman Mythology in the Basic Stage, The Classic of Mountains and Rivers (Stories), 2015 (2): 88-89. 